\title{
A remote sensing and GIS based study in assessment of the degradation risk of the Kolonnawa marsh
}

\author{
Y.M.P. Samarasinghe and N.D.K. Dayawansa* \\ Department of Agricultural Engineering, Faculty of Agriculture, University of Peradeniya, Peradeniya.
}

\begin{abstract}
A majority of the Sri Lankan wetlands is under threat of degradation mainly due to urbanization, population pressure and industrialization. This study was conducted to detect the changes and to assess and map the degradation risk of the Kolonnawa marsh located in the Western Province of Sri Lanka by analyzing the data collected through field surveys, remote sensing and GIS techniques. A questionnaire survey was conducted within 11 Grama Niladhari (GN) Divisions around the marsh to obtain information on household characteristics, interactions with the marsh, awareness on marsh degradation and marsh conservation. According to the temporal change assessment performed with Landsat TM (1992), Landsat ETM+ (2002) satellite images, $32 \%$ of the marsh area has been reduced in $1992-2002$ period. According to Worldview 2 image, the total marsh area including the associated waterways in 2010 was 144.56 ha. A risk index was formulated considering the risk factors prevailing in the study area. Risk mapping, which was carried out based on the risk index resulted in three risk classes; moderate, high and very high. Mapping based on the risk index was helpful to identify the severity of the degradation risk of the marsh at GN Division level. The study identified that all surrounding GN Divisions pose risk on degradation of the marsh while the highest impact was reported from the Obesekarapura GN Division. The risk matrix was identified as an important tool in prioritizing the areas for conservation.
\end{abstract}

Keywords: Anthropogenic activities, degradation risk, Kolonnawa marsh, risk mapping, temporal changes.

\section{INTRODUCTION}

The wetlands function as essential environmental components and are vital natural resources, which provide ecological, economical, socio-cultural, scientific and recreational services to the country (Barbier, 1994). They are characterized with emergent plants growing in soils that are periodically or continuously saturated with water and comprise immense biological diversity in which a large number of plants and animals survive (Chouhan, 2008). Other wetland functions include breakage of toxic compounds after absorption by wetland plants, prevention of soil erosion by reducing the velocity of flow allowing silt to settle and reduction of siltation in water bodies (Chaves \& Lakshumanan, 2008; USEPA, 2009). By recycling nitrogen, they improve the water quality of downstream water bodies (Barbier et al., 1997). Wetlands absorb the excess water of rivers and streams in heavy rain periods and delay its release (Smith et al., 1995). Thus, they provide social and economic values to humans by controlling flood. The degradation risk of wetlands is becoming a serious problem in many parts of the world due to rapid increase of population and the resulting pressure on natural resources (Turner, 1991; Koch et al., 2001; Mitsch \& Gosselink, 2007). Factors such as loss of wetland area, changes to the water regime, changes in water quality, over-exploitation of wetland products and introduction of alien species have increased and wetland degradation has been amplified (Shine \& de Klemm, 1999). Destruction and degradation of wetlands can lead to serious consequences such as increasing flooding, extinction of species and declining water quality (Shine \& de Klemm, 1999; USEPA, 2004; Kotagama \& Bambaradeniya 2006).

Sri Lanka is rich in wetland ecosystems, which are associated with the river system of the country (Kotagama \& Bambaradeniya, 2006). The Kolonnawa

*Corresponding author (dammid@pdn.ac.lk) 
marsh is one of them located in the Colombo District in the Western Province and surrounded by highly populated and industrialized sites. The wetland is excessively used by the people in the vicinity for income generation such as for fishing, cattle grazing, and collecting firewood and for the purpose of garbage disposal. Another significant risk to the wetland is land reclamation and recreational activities (Marawila \& Thibbotuwawa, 2010). Degradation of the marsh has resulted in the reduction of flood detention capacity and increased flood incidents in the Colombo District. Flooding has become the most costly disaster in terms of properties and humans throughout the last century (Jayasekara, 2009). Wetlands are important in regulating the quality and quantity of water in downstream water resources (Hategekimana \& Twarabamenye, 2007). Hence, quality deterioration and quantity changes of hydrologically connected water bodies can be expected. Degradation of the quality of wetlands also affects loss of important native plant species, loss of fish breeding sites and the reduction of aesthetic appearance of the marsh.

The identification of areas under high risk is essential to start remediation actions and to prevent further degradation. The approaches, which are totally based on field surveys to identify risk areas is time consuming and costly. The data collected through remote sensing techniques will be very advantageous to overcome these problems. Also, it will help to collect data of inaccessible areas (Harvey \& Hill, 2001). Hence, the study was conducted with the objective of assessing and mapping of risk areas in the Kolonnawa marsh and its adjacent catchment area using Remote Sensing, Geographical Information System (GIS) and field data.

\section{METHODS AND MATERIALS}

\section{Study area}

The selected study area (Figure 1), was the Kolonnawa marsh, which is located in the Colombo District of the Western Province. It belongs to the Colombo Marsh complex, that consists of Kolonnawa, Kotte and Heen Marsh.

The primary and secondary data were used for the study. Ground truth information and household information were collected using a field survey. As secondary data, the spatial and non-spatial data were collected. ERDAS IMAGINE and ArcGIS software were used for remotely sensed data analysis and GIS analysis.

The study area was extracted from the topographic map $(1: 50000)$ of Colombo. Landsat TM (1992) and Landsat ETM+ (2002) images with $30 \mathrm{~m}$ spatial resolution were used in the study. Images were geometrically corrected and co - registered. World View 2 satellite image of 2010 was also used as a reference image although it has a high spatial resolution (1.84 $\mathrm{m}$ ) compared to Landsat TM and ETM+ images.

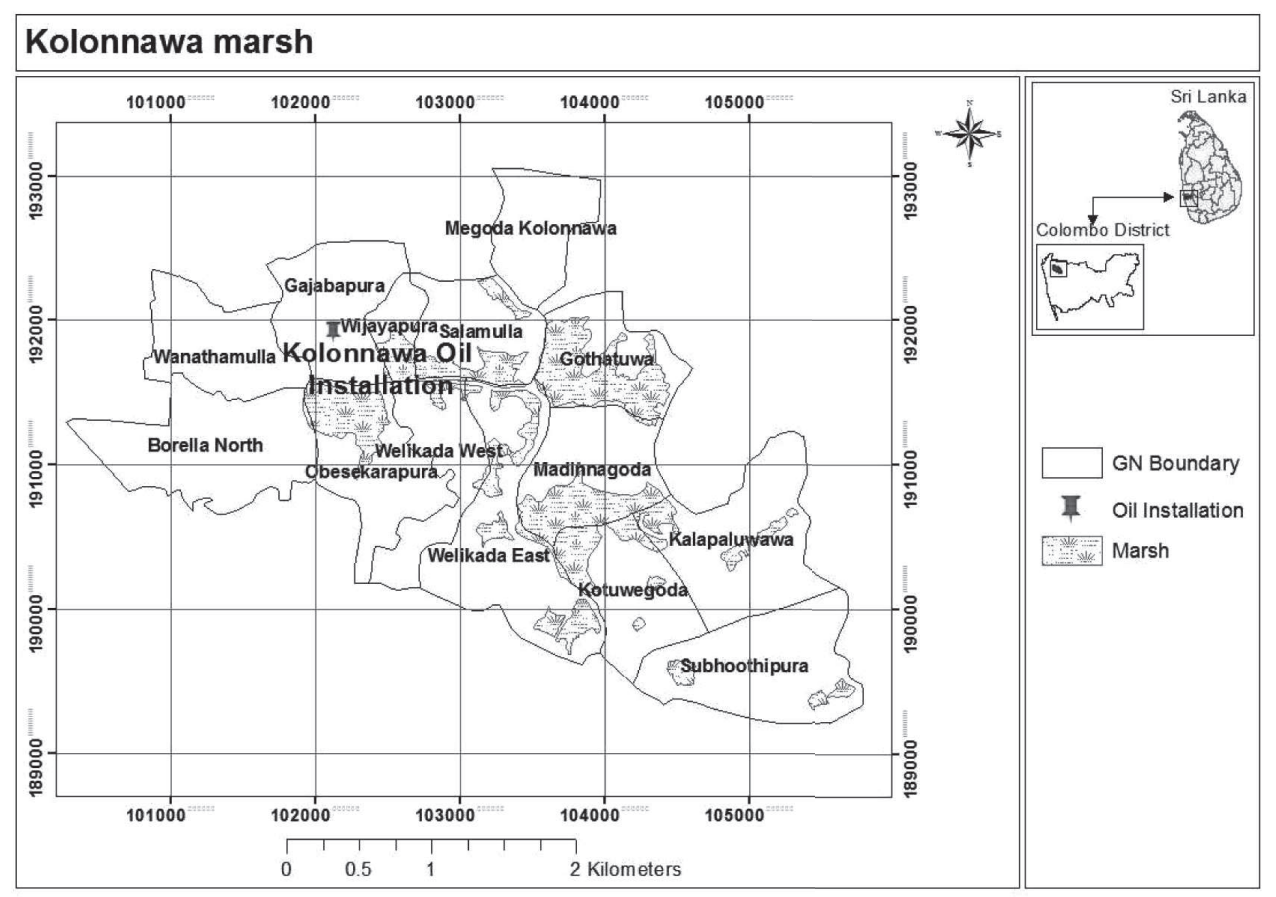

Figure 1: The study area - Kolonnawa marsh 
Landsat TM and ETM+ images were classified to identify the marsh area (including water) and other land uses by a combination of supervised classification and interpretation of normalized difference vegetation index (NDVI) images. Since the World View satellite imagery is of high spatial resolution, visual interpretation was done to identify land use classes.

Eleven (11) Grama Niladhari (GN) Divisions surrounding the marsh area were selected for the risk assessment. A field survey was conducted to identify the risk factors on marsh degradation in the above GN Divisions. A questionnaire survey was conducted in 99 households to obtain information on household characteristics, interactions with the marsh, awareness on marsh degradation and marsh conservation.

A risk matrix was developed in Microsoft Excel (www.dot.ca.gov; www.spms.ntu.edu.sg/mas). The risk matrix for the Kolonnawa marsh was developed by considering the significant risk factors, which were identified as most appropriate, namely; reduction of wetland area, organic pollution, exploitation of biological products, reduction of biological diversity, and presence of risky land uses. Weights were assigned to each key risk factor according to their significance within the study area and the particular weight was allocated among sub - risk factors considering their implication on the marsh. All the sub - risk factors were assessed under 3 categories as; extent of the issue, permanence and the irreversibility of the issues. Risk values were given to each after analysing primary and secondary data. The scale of risk was identified at 4 levels namely; low, medium, high and very high. The overall risk was calculated for each GN Division after calculating the total risk for the key factors. The risk index was formulated with regard to the overall risk of the GN Division as indicated in equation 1.

$$
\text { Risk Index }=\frac{\text { Total risk value for a given area }}{\text { Maximum possible risk value }}
$$

Finally, the risk mapping was carried out based on the key risk factors and the risk index.

\section{RESULTS AND DISCUSSION}

\section{Selection of marsh area for risk assessment}

Although the following of natural boundaries is more convenient for an environmental study, $11 \mathrm{GN}$ Divisions surrounding the marsh were selected due to the large catchment area occured as a result of the flat landscape. Also the data used for risk index calculation such as population density and economic status were available only at GN Division level. The marsh occupied $15 \mathrm{GN}$ Divisions according to the 1:50000 scale topographic map. However at present, the marsh spreads only within $10 \mathrm{GN}$ Divisions. In addition, the Gajabapura GN Division was also considered due to the presence of the Kolonnawa Oil Installation, which poses a considerable threat to the marsh due to possible oil spilling and leakages as identified in the initial field visit.

\section{Management of the marsh area}

The field observations helped to obtain a thorough understanding of the issues in the Kolonnawa marsh. A part of the marsh had been acquired by the Sri Lanka Land Reclamation and Development Corporation (SLLRDC) under section 2 of the Act No. 15 of 1968 with the objective of reclamation of marshy and low lying areas (www.landreclamation.lk). Since then, a large number of reclamation activities have been conducted and many low lying marshy lands have been lost to the country. It has led to the loss of most of the Colombo water retention areas and has led to increased flood incidences of the Colombo District during the last few decades. Later, realizing the negative effects of land reclamation, such activities were prohibited without permission from the SLLRDC and the Central Environmental Authority (CEA) (www.landreclamation.lk). Although rules and regulations are in place as indicated, activities which pollute the water bodies and illegal encroachments could be observed within the study area. SLLRDC has constructed a peripheral canal around the marsh, mainly to prevent further encroachments and for facilitating proper drainage. Although the main canal system is maintained properly by removing invasive plants, the entire peripheral canal system is invaded by these plants and no rehabilitation activity has been carried out recently.

\section{Socio-economic characteristics}

According to the socio economic analysis, the highest population density was observed in the Obesekarapura GN Division, which leads to increased interactions with the marsh and contribution to pollution (Figure 2). Although the lowest per capita income of 5089 rupees was reported from the Welikada West GN Division, the highest percentage of Samurdhi beneficiaries $(2.85 \%)$ was reported from the Gothatuwa GN Division. The field survey revealed that $41 \%$ of the surveyed sample does not have the ownership of land and are considered 


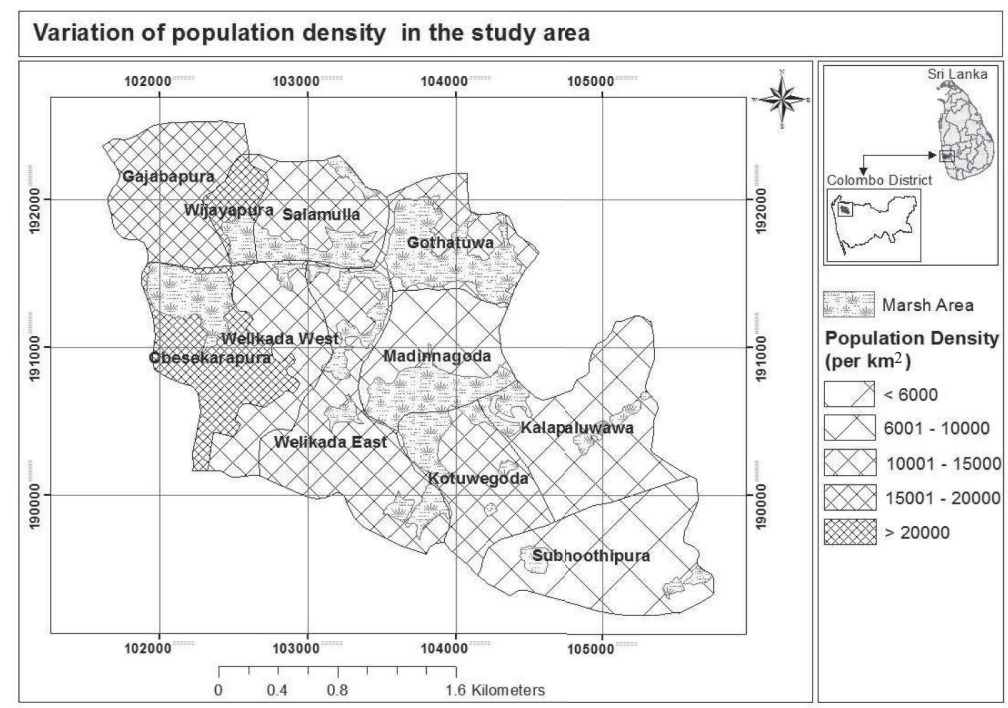

Figure 2: Variation of population density in the study area

as illegal encroachers. All the sampled households in the Obesekarapura and the Welikada West GN Divisions were illegal encroachers.

The direct discharge of toilet waste to the marsh was identified in $12 \%$ of the dwellings surveyed and the highest discharge was reported in the Obesekarapura GN Division. Lack of proper toilet facilities, as a result of poor social status of the occupants, is the main reason for the above situation. Per-capita water consumption was the indicator used to assess the per-capita liquid waste generation. In general, people use $65 \%$ of the total water consumption for toilets, shower and washing (USEPA, 2004) and this value was used for the calculation of liquid waste generation. The highest liquid waste generation was reported from the Welikada East GN Division based on the highest water consumption (Figure 3). Further, it was not possible to identify an exact reason for high water use, the sophisticated lifestyle of the dwellers may have contributed to it. Although a solid waste collection system was available in all GN Divisions, $20 \%$ of the sample discarded the waste directly to the marsh. According to the occupants, the outsiders also throw their waste to the marsh. Elevated nutrient levels created by solid and liquid wastes, excreta and animal wastes may be the reasons behind excessive growth of invasive plant species and algae. Besides, the awareness among the residents on the importance of the marsh was poor and this was common across all education levels. It was apparent that the community did not show any

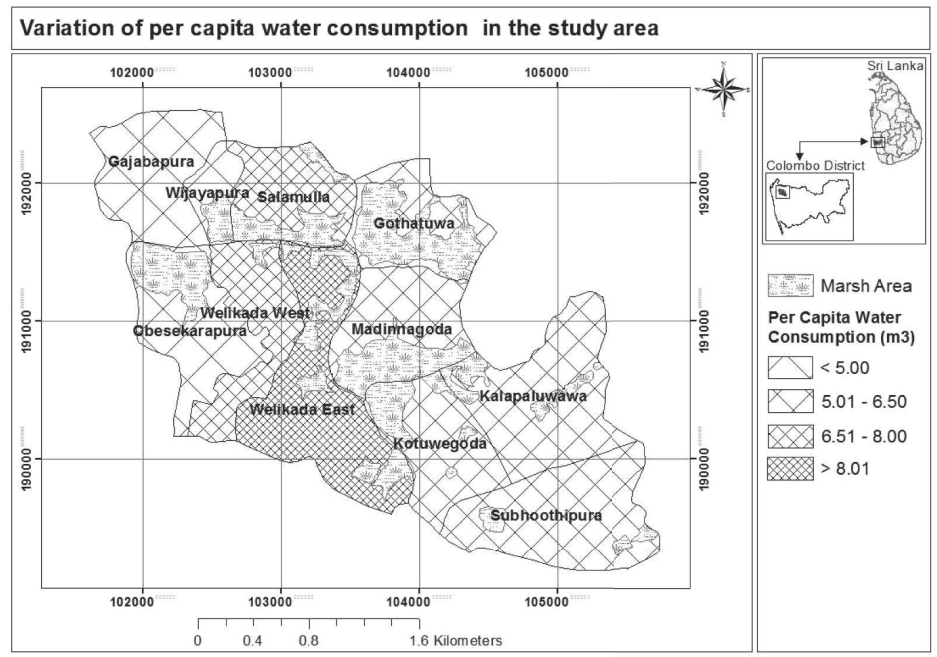

Figure 3: Variation of monthly per capita water consumption in the study area 
interest in environmental protection. No community based organization on wetland protection was found within the whole study area and no conservation action has been taken at community level. A large scale reclamation and land filling activities were observed in Kalapaluwawa, Kotuwegoda and Subhoothipura GN Divisions.

\section{Detection of changes in marsh area}

The NDVI images together with false colour composites were used to identify the marsh area from other areas. Although NDVI is widely used for vegetation identification, it was used for this study since the Kolonnawa marsh is highly associated with vegetation. However, the spectral confusion was the major obstacle in identifying the wetland area from other areas.

According to the change detection, in 1992 the extent of the marsh area was 419 ha and it has decreased to 285 ha in 2002. It is $32 \%$ of gross marsh area reduction compared to 1992 . The total marsh area including the associated waterways in 2010 was 144.56 ha. Though it is not possible to compare outputs obtained from images of two different spatial resolutions, the comparison of the values showed that, change of the marsh area from

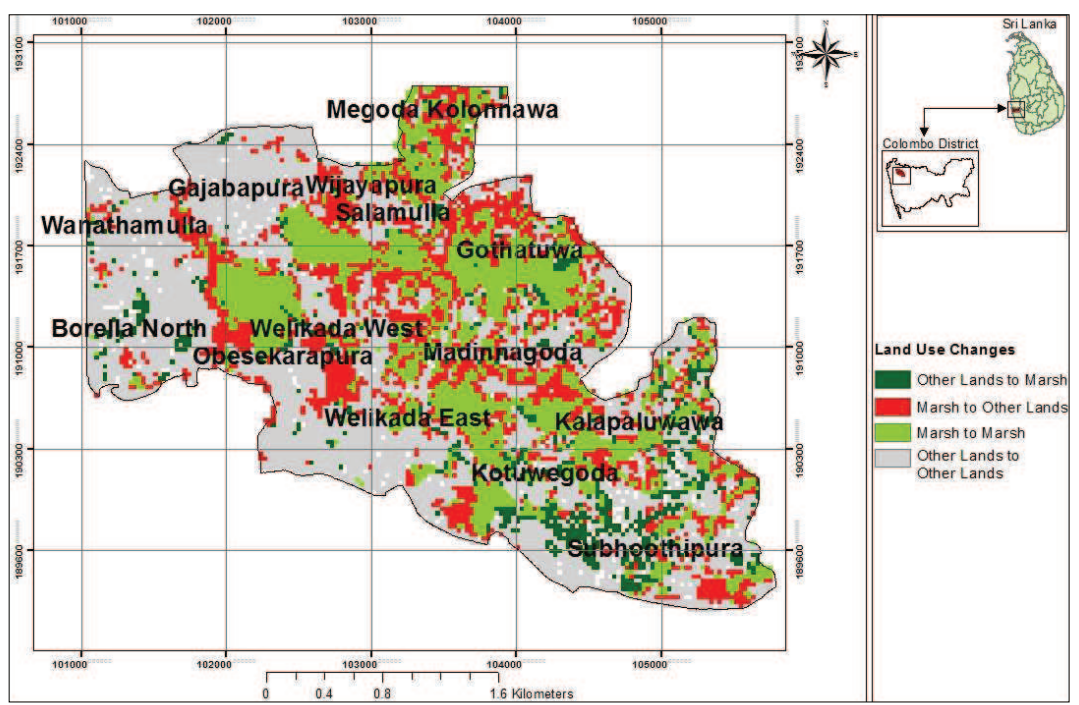

Figure 4: Physical changes in the Kolonnawa marsh during 1992 - 2002

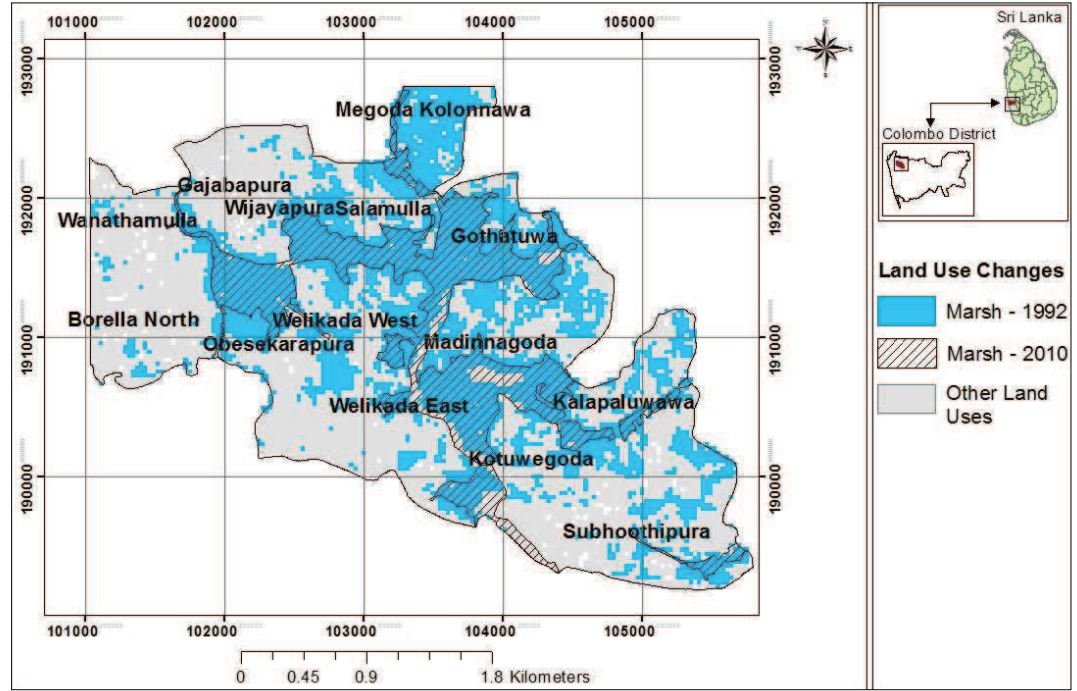

Figure 5: Physical changes in the Kolonnawa marsh during 1992 - 2010 
2002 to 2010 was $49 \%$ of the 2002 marsh area. When compared to 1992 , it was a $65 \%$ of marsh area reduction. Figure 4 illustrates the changes of marsh area during 1992 to 2002 and Figure 5 illustrates the changes from 1992 to 2010 .

\section{Assessment of risk on the marsh}

The equation 2 presents the weights assigned to each factor considered in the risk analysis. The weights were decided based on the information collected for each risk factor during the field visits, and by considering their relative contribution towards wetland degradation. by considering reclamation and land filling activities (percentage marsh area change from 1992 to 2010) and illegal encroachments (percentage households without land ownership). Urban solid wastes (percentage direct solid waste disposal), excreta (percentage direct excreta discharge incidences), liquid wastes (water consumption) and livestock wastes (percentage households rearing animals) were considered to evaluate the organic pollution of the marsh.

The exploitation of biological products was analyzed by considering the population density and economic status since high population pressure and low economic

Total risk $=(12 *$ Reclamation and land filling $+8 *$ Illegal encroachments $)+(4 *$ Urban solid waste $+8 *$ Excreta + $4 *$ Liquid waste $+4 *$ Livestock waste $)+(3 *$ Population density $+3 *$ Economic status $)+(8 *$ Presence of invasive species in the marsh $+8 *$ Presence of Invasive species in the canal $+4 *$ Firewood collection and cultivation in the marsh $)+(8 *$ Presence of residential sites $+12 *$ Presence of industrial sites $)$

Risk matrices (Figure 6) were developed for each GN Division under five main categories; reduction of wetland area, organic pollution, exploitation of biological products, reduction of biological diversity and presence of risky land uses. The wetland area reduction was assessed status resulted in increased interactions with the marsh. More than $90 \%$ of the wetland is covered with invasive plant species, Annona glabra and Eichhornia crassipes. Firewood collection and cultivation within the marsh were observed as threats. Hence, the presence of invasive

\begin{tabular}{|c|c|c|c|c|c|c|c|c|c|c|c|}
\hline \multicolumn{12}{|c|}{ Kotuwegoda GN Division } \\
\hline & \multicolumn{11}{|c|}{ Wetland Risk Analysis (For Kolonnawa Marsh) } \\
\hline & Major Risk $\mathrm{F}$ actor & Sub Risk Factor & 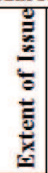 & : & 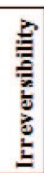 & & & $\frac{\text { uㅡㄹ }}{\underline{z}}$ & $\begin{array}{l}\frac{y}{\tilde{z}} \\
\frac{\mathrm{E}}{\mathrm{E}} \\
\frac{\mathrm{E}}{\mathrm{E}}\end{array}$ & 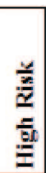 & 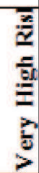 \\
\hline \multirow[t]{3}{*}{1} & Reduction of Wetland Area & Reclamation and Land Filling & 2 & 2 & 2 & 72 & 3 & & & & \\
\hline & & Illegal Encroachments & 5 & 1 & 1 & 56 & 4 & & & & \\
\hline & & & & & & 128 & 3 & & & & \\
\hline \multirow[t]{5}{*}{2} & Organic Pollution & Urban Solid Waste & 2 & 2 & 1 & 20 & 3 & & & & \\
\hline & & Excreta & 3 & 2 & 1 & 48 & 3 & & & & \\
\hline & & Liquid Waste & 4 & 2 & 2 & 32 & 4 & & & & \\
\hline & & Livestock Waste & 0 & & & 0 & 0 & & & & \\
\hline & & & & & & 100 & 3 & & & & \\
\hline \multirow[t]{3}{*}{3} & Exploitation of Biological Products & Population density & 2 & 2 & 2 & 18 & 3 & & & & \\
\hline & & Economic status & 2 & 1 & 1 & 12 & 2 & & & & \\
\hline & & & & & & 30 & 3 & & & & \\
\hline \multirow[t]{4}{*}{4} & Reduction of Biological Diversity & Presence of Invasive Species in the Marsh & 5 & 2 & 2 & 72 & 4 & & & & \\
\hline & & Presence of Invasive Species in Major Canals & 2 & 1 & 1 & 32 & 2 & & & & \\
\hline & & Firewood Collection and Cultivation in the Mars & 1 & 1 & 1 & 12 & 2 & & & & \\
\hline & & & & & & 116 & 3 & & & & \\
\hline \multirow[t]{8}{*}{5} & Presence of Risky Land Uses. & Presence of residential sites & 3 & $1]$ & 2 & 48 & 3 & & & & \\
\hline & & Presence of Industrial sites & 0 & & & 0 & 0 & & & & \\
\hline & & & & & & 48 & 2 & & & & \\
\hline & & & & & & & & & & & \\
\hline & & & & & & & & & & & \\
\hline & Total Risk due to extent of issue & & 128 & & & & & & & & \\
\hline & Total Risk & & & & & 422 & & & & & \\
\hline & Risk Index & & & & & 0.55 & & & & & \\
\hline
\end{tabular}

Figure 6: Degradation risk matrix for the Kolonnawa marsh 
species, firewood collection and cultivation within the marsh were used to assess the reduction of biological diversity. Presence of industrial and residential sites was considered to measure the risk due to risky land uses. The risk index ranged between 0 and 1 ; values close to 0 indicated low risk and values close to 1 indicated high risk.

\section{Risk mapping}

The preparation of risk maps separately for each key risk factor facilitates the interpretation of risk. As presented in Figure 7, Obesekarapura, Welikade West and Salamulla GN Divisions pose a very high risk of physical changes. It implies that a high number of land filling activities had undergone in the area from 1992 to 2010 and the percentage of illegal encroachments is high. The Gajabapura and the Welikada East GN Divisions pose a moderate risk. The Gajabapura GN Division does not contain the marsh at present and the social status of the occupants in both Divisions was comparatively at a higher level. This leads to less interaction with the marsh and less risk of physical changes.

The Obesekarapura and the Kotuwegoda Divisions pose a high risk of organic pollution on the marsh, mainly due to direct disposal of human excreta. The highest risk of exploitation of biological products was also identified

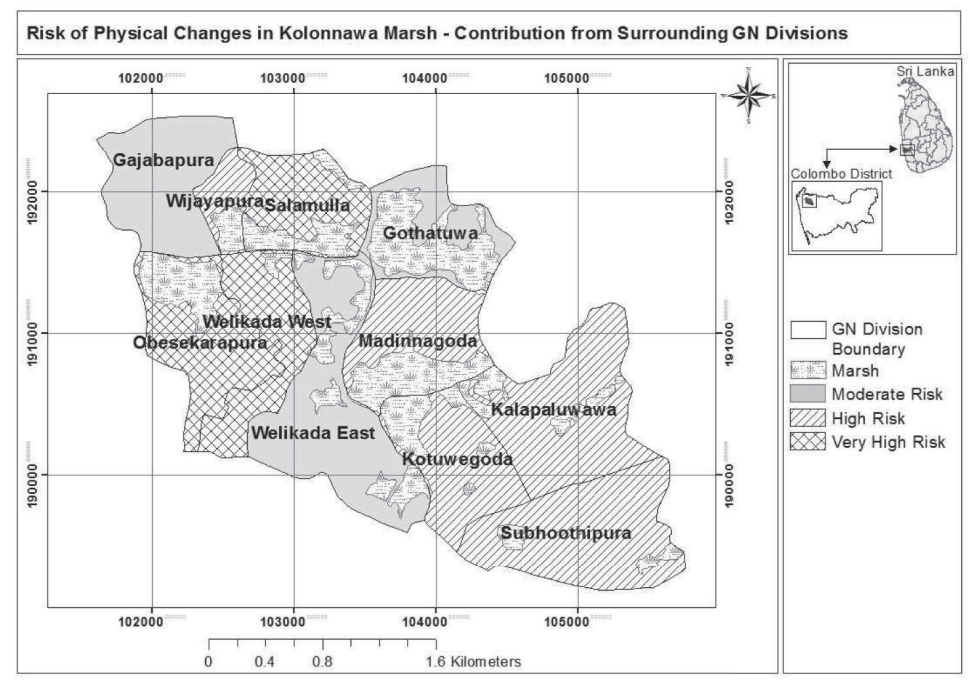

Figure 7: Risk of physical changes in the Kolonnawa marsh - contribution from surrounding GN divisions

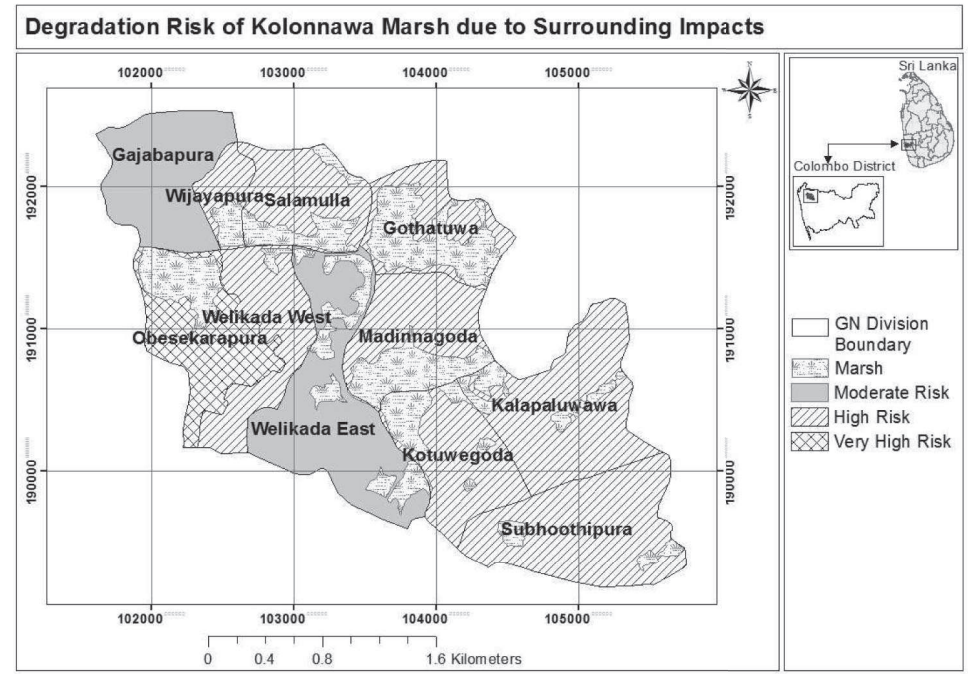

Figure 8: Degradation risk of the Kolonnawa marsh due to surrounding impacts 
in Obesekarapura as a result of high population pressure. Land uses in the Gajabapura GN Division pose a very high risk for degradation of marsh due to presence of the Kolonnawa Oil Installation.

The risk of reduction of biological diversity was high in all GN Divisions except Gajabapura. Spreading of invasive species was observed as a severe threat in all GN Divisions.

Figure 8 presents the overall risk on the marsh area. Accordingly, all GN Divisions pose risks on the Kolonnawa marsh. The Obesekarapura GN Division is in the high risk category as a result of the large scale physical changes taking place in the marsh, exploitation of biological products followed by high population pressure and high risk of organic pollution. The Gajabapura and the Welikada East GN Divisions account for moderate risk. The Gajabapura GN Division has a low risk of reduction of biological diversity, low risk of organic pollution and moderate risk of the physical changes, which ultimately contribute to moderate risk on marsh degradation. The Welikada East GN Division has a low risk of organic pollution, moderate risk of physical change and moderate contribution of land uses for the degradation of the marsh.

\section{Limitations of the study}

It is important to consider satellite images with similar spatial resolution for change detection. Therefore, a combination of moderate and high spatial resolution imagery used for detecting the change may not produce very accurate results and was identified as a limitation in this study. It is possible to over or under-estimate the area under marsh when using satellite images with medium spatial resolution. Classification accuracy assessment is also needed to identify the level of accuracy in identification of marsh.

When selecting samples for the questionnaire survey, it is better to use a sample proportionate to the population in each GN Division. Based on the assumption that the impact of households reduces with the distance from the marsh, and due to practical difficulties like reluctance to provide information by the households, sampling had to be restricted to a small number of households located close to the marsh area.

The risk matrix produced for Kolonnawa marsh is a generalized one for the selected study area. However, specific issues may be present in some locations, which would not be considered seriously in risk assessment. As an example, the oil installation in the Gajabapura GN Division poses a heavy risk of possible oil pollution. However, the present risk matrix is not suitable to identify and quantify it as a severe risk since oil installation is also categorized under the presence of industrial sites. Factors such as hydrological modifications should also be taken into consideration in assessing risk of degradation of the marsh.

\section{CONCLUSION}

A significant reduction of the Kolonnawa marsh area is reported from 1992 to 2010 . The change of the marsh area in 2010 is $65 \%$ compared to 1992 . Liquid and solid waste disposal, human excreta discharge, reclamation and land filling, high population density, illegal encroachments and the presence of invasive species were identified as significant threats to the marsh.

When the overall risk is considered, all surrounding GN Divisions pose a risk on degradation of the marsh. The highest impact was reported from the Obesekarapura GN Division. Awareness on the importance of the marsh is very poor among people in the vicinity irrespective of their education status. Hence, awareness creation is an important factor in reducing the degradation risk of the Kolonnawa marsh. No community based organizations were reported for environmental protection in this area showing the low interest among people on environmental conservation activities.

\section{REFERENCES}

1. Barbier E.B. (1994). Valuing environmental functions: tropical wetlands. Land Economics 70(02): 155 - 173. DOI: http://dx.doi.org/10.2307/3146319

2. Barbier E.B., Acreman M. \& Knowler D. (1997). Economic Valuation of Wetlands. A Guide for Policy Makers and Planers. Ramsar Convention Bureau, Gland, Switzerland. Available at http:// liveassets. iucn. getunik. net/ downloads/03e_economic_valuation_of_wetlands.pdf, Accessed 9 October 2011.

3. Chaves A.B. \& Lukshumanan C. (2008). Remote sensing and GIS - based integrated study and analysis for mangrove - wetland restoration in Ennore Creek, Chennai, South India. Proceeding of Tall 2007: 12 $2^{\text {th }}$ World Lake Conference (eds. M. Sengupta \& P. Dalvani). pp. $685-690$.

4. Chouhan P. (2008). Save wetlands save water, Proceeding of Tall 2007: $12^{\text {th }}$ World Lake Conference (eds. M. Senguptha \& P. Dalvani), International Lake Environment Committee, Jaipur, India, pp.1315 - 1320.

5. Harvey K.R. \& Hill G.J.E. (2001). Vegetation mapping of a tropical freshwater swamp in the Northern Territory, 
Austrailia: a comparison of aerial photography, Landsat TM and SPOT satellite imagery. International Journal of Remote Sensing 22(15): 2911-2925.

6. Hategekimana S. \& Twarabamenye E. (2007). The impacts of wetland degradation on water resources management in Rwanda: the case of Rugezi Marsh. International Symposium on Hydrology. pages

7. Jayasekara S.R. (2009). Innovative Strategies towards flood Resilient Cites in Asia Pacific, Bangkok. Country Report Sri Lanka. Available at www.unescap.org/idd/events/2009 EGM-DRR/index.asp, Accessed 31 August, 2011.

8. Koch M., Schmid T. \& Gumuzzio J. (2001). The study of anthropogenic affected wetlands in semi-arid environments applying airborne Hyper-spectral Data. Teledeteccion, Medio Ambientey Cambio Global, 297-301.

9. Kotagama S.W. \& Bambaradeniya C.N.B. (2006). An overview of wetlands of Sri Lanka and their conservation significance, National Wetland Directory of Sri Lanka, Colombo, Sri Lanka.

10. Marawila T.D. \& Thibbotuwawa M. (2010). To Develop or to Conserve? The case of the Diyawanna Oya Wetland in Sri Lanka, South Asian Network for Development Environmental Economics, Working paper, 52 - 10.

11. Mitsch W.J. \& Gosselink J.G. (2007). Wetlands. 4th edition. pp. 582. J. Wiley and Sons, Hoboken, New Jersey.

12. Shine C. \& de Klemm C. (1999). Wetlands, Water and the Law. Using law to advance wetland conservation and wise use, pp 8-20. IUCN, Gland, Switzerland, Cambridge, UK and Bonn, Germany.
13. Smith R.D., Ammann A., Bartoldus C. \& Brinson M.M. (1995). An approach for assessing wetland functions using hydro-geomorphic classification, reference wetlands and functional indices. Wetlands Research Program Technical Report WRP-DE-9. Waterways Experiment Station, US Army Corps of Engineers.

14. Turner K. (1991). Economics and Wetland Management. Ambio 20(2): 59 - 63 .

15. Risk Assessment Templates. Available at http://www. spms.ntu.edu.sg/mas/Safety/Safety_Doc/RA\%20SPMS\%20 180512.xls, Accessed 20 October 2011.

16. Project Risk Management, Project Management. Available at http://www.dot.ca.gov/hq/projmgmt/guidance_prmhb. htm, Accessed 20 October 2011.

17. United States Environmental Protection Agency (USEPA) (2004). Wetland Overview. Available at http://www.water. epa.gov/type/wetlands/outreach/upload/overview.pdf, Accessed 12 August 2011.

18. United States Environmental Protection Agency (USEPA) (2009). Wetland Functions and Values, Distances Learning Modules on Watershed Management. Available at http:// cfpub.epa.gov/watertrain/pdf/modules/WetlandsFunctions. $p d f$. Accessed 3 June 2011.

19. Sri Lanka Land Reclamation \& Development Corporation. Available at $h t t p: / / w w w$. landreclamation.lk, Accessed 22 July 2011. dot.ca.gov/hq/projmgmt/guidance_prmhb.htm, Accessed on 20th October, 2011. 